\title{
Molecular and Aggressiveness Characterization of Isolates of Fusarium solani and Fusarium oxysporum f.sp. passiflorae Associated to Passion Fruit Wilting
}

\author{
Thalita N. Marostega ${ }^{1}$, Lizandra P. Lara ${ }^{1}$, Daiani da S. de Oliveira ${ }^{1}$, Antonio M. Chimello ${ }^{1}$, \\ Thiago Alexandre S. Gilio ${ }^{1}$, Sandra da C. Preisigke ${ }^{2}$, Kelly L. Araujo ${ }^{1}$, Milson E. Serafim ${ }^{3}$ \\ \& Leonarda G. Neves ${ }^{1}$ \\ ${ }^{1}$ School of Agronomy, Mato Grosso State University, Cáceres, Brazil \\ ${ }^{2}$ School of Agronomy, State University of North Fluminense, Campos dos Goytacazes, Brazil \\ ${ }^{3}$ Federal Institute of Mato Grosso, Cáceres, Brazil \\ Correspondence: Thalita N. Marostega, School of Agronomy, Mato Grosso State University, Cáceres, 78200-000, \\ Brazil. Tel: 55-65-3211-2847. E-mail: tamarostega@gmail.com
}

Received: November 6, 2018

Accepted: December 20, 2018

Online Published: February 15, 2019

doi:10.5539/jas.v11n3p407

URL: https://doi.org/10.5539/jas.v11n3p407

\begin{abstract}
This work was carried out with the objective of performing a molecular and aggressiveness characterization of $F$. solani and F. oxysporum f.sp. passiflorae collected in the Pantanal, Cerrado and Amazon biomes. We selected the most aggressive isolates for use in breeding programs aiming resistance to Collar Rot and Fusariosis. For inoculation of the isolates of $F$. oxysporum f.sp. passiflorae the washed root method was used. The molecular characterization of the isolates was carried out by partial sequencing of the Transcribed Internal Spacer of the rDNA region. The isolates of $F$. solani formed two distinct groups in relation to aggressiveness. Among all isolates, FSUNEMAT 40 and FSUNEMAT 46 were the most aggressive. The model with $\mathrm{K}=2$ was taken as the best model to explain the genetic structure of the $F$. solani populations, with clear combinations of genes from both gene pools. There were three groups with respect to the aggressiveness of the isolates of $F$. oxysporum f.sp. passiflorae, with the isolated FOUNEMAT 22 being the most aggressive. In view of these results, the isolates of $F$. solani collected in P. edulis in the state of Mato Grosso presented a high molecular variability independent from the biome of origin, and this was also observed in the tests of aggressiveness. The results indicate the need to consider the molecular variability and the aggressiveness of the pathogens in the evaluation of genotypes of sour passion fruit in programs of selection of resistant cultivars.
\end{abstract}

Keywords: Passiflora edulis, resistance, breeding programs, phytopathogen

\section{Introduction}

The cultivation of passion fruit, Passiflora edulis, has been growing every year in Brazil, occupying a prominent position in tropical fruit growing (MAPA, 2016). The state of Mato Grosso is the largest producer in the Midwest region, totaling 5,275 tons in a cultivated area of 346 hectares. This production is still very low when compared to the state of Bahia, which produces an average of 342 thousand tons/year (IBGE, 2016).

One of the main problems that contributes to the reduction in productivity of the passion fruit crop is the occurrence of diseases, such as collar rot and fusariosis, caused respectively by the fungi Fusarium solani Martius and Fusarium oxysporum f.sp. passiflorae (Fischer \& Rezende, 2008). Plants infected by these fungi initially present wilting of the nodes and, with the progress of the disease, there is early defoliation, wilting and death of the plant in a few days. These symptoms are the result of the damage caused by these fungi to the vascular system of plants (Fischer \& Rezende, 2016). The presence of $F$. solani and F. oxysporum f.sp. passiflorae in the soil may even prevent the cultivation of passion fruit for years since these pathogens have a resistance structure (chlamydospore) that guarantees fungus survival (Bueno et al., 2006).

One of the most current alternatives for the control of diseases in passion fruit is the use of resistant cultivars (Silva et al., 2012). However, there are still no passion fruit cultivars resistant to collar rot and fusariosis recorded in the Ministry of Livestock and Supply. In this context, knowledge on the pathogenicity and variability of the pathogen 
population is indispensable for breeding programs aiming the selection of a resistant passion flower cultivar or a hybrid in view of the complex pathosystem, where the pathogen involved presents a genetic variability, as reported by previous studies (Carvalho et al., 2015; Dariva et al., 2015; Silva et al., 2017).

In this sense, this work was carried out with the objective of performing a molecular and aggressiveness characterization of F. solani and F. oxysporum f.sp. passiflorae collected in the Pantanal, Cerrado and Amazon biomes. We selected the most aggressive isolates for use in breeding programs aiming resistance to Collar Rot and Fusariosis.

\section{Methods}

\subsection{Characterization of Aggressiveness}

Sixteen isolates of $F$. solani and eight isolates of $F$. oxysporum f.sp. passiflorae belonging to the collection of the State University of Mato Grosso (UNEMAT) were selected for characterization of aggressiveness in $P$. edulis (Tables 1 and 2). All isolates were collected from plants presenting symptoms of wilting in passion fruit producing areas, including the three biomes of the state of Mato Grosso: Pantanal, Cerrado and Amazon (Carvalho et al., 2015). All isolates are preserved in the UNEMAT fungi collection in filter paper strips stored in a refrigerator at \pm $5{ }^{\circ} \mathrm{C}$.

Table 1. Relation of Fusarium solani isolates used in the aggression test

\begin{tabular}{llll}
\hline Treatment & N $^{\text {of Collection }}$ & Origin & Biomes \\
\hline 1 & FSUNEMAT 4 & São José dos Quatro Marcos & Amazon \\
2 & FSUNEMAT 7 & São José dos Quatro Marcos & Amazon \\
3 & FSUNEMAT 12 & São José dos Quatro Marcos & Amazon \\
4 & FSUNEMAT 17 & Curvelândia & Amazon \\
5 & FSUNEMAT 21 & Carlinda & Amazon \\
6 & FSUNEMAT 25 & Alta Floresta & Amazon \\
7 & FSUNEMAT 28 & Carlinda & Amazon \\
8 & FSUNEMAT 31 & Nossa Sra do Livramento & Pantanal \\
9 & FSUNEMAT 33 & Santo Antônio do Leverger & Pantanal \\
10 & FSUNEMAT 34 & Santo Antônio do Leverger & Pantanal \\
11 & FSUNEMAT 35 & Santo Antônio do Leverger & Pantanal \\
12 & FSUNEMAT 38 & Santo Antônio do Leverger & Pantanal \\
13 & FSUNEMAT 40 & Campo Verde & Cerrado \\
14 & FSUNEMAT 46 & Santo Antônio do Leverger & Pantanal \\
15 & FSUNEMAT 47 & Campo Verde & Cerrado \\
16 & FSUNEMAT 50 & Campo Verde & Cerrado \\
\hline
\end{tabular}

Table 2. Relation of Fusarium oxysporum f.sp. passiflorae isolates used in the aggression test

\begin{tabular}{llll}
\hline Treatment & N $^{\text {of Collection }}$ & Origin & Biomes \\
\hline 1 & FOUNEMAT 3 & Cáceres & Cerrado \\
2 & FOUNEMAT 5 & Cáceres & Pantanal \\
3 & FOUNEMAT 6 & São José dos Quatro Marcos & Amazon \\
4 & FOUNEMAT 9 & Nova Lacerda & Cerrado \\
5 & FOUNEMAT 13 & Indiavaí & Amazon \\
6 & FOUNEMAT 22 & Carlinda & Amazon \\
7 & FOUNEMAT 41 & Campo Verde & Cerrado \\
8 & FOUNEMAT 43 & Campo Verede & Cerrado \\
\hline
\end{tabular}

In order to characterize the aggressiveness, clones (cuttings) were produced from a $P$. edulis plant, accession UFV50, belonging to the GAB (Germplasm Active Bank) of UNEMAT. The cuttings contained three internodes. Then, they were planted in trays of 72 cells containing Plantmax ${ }^{\circledR}$ substrate (Eucatex Mineral Ltda.) and kept in a greenhouse under controlled irrigation and two weekly applications of leaf fertilizer in order to stimulate plant 
rooting. The whole period lasted approximately three months until the stakes reached $\pm 20 \mathrm{~cm}$ in height. After rooting, for the experiment on $F$. solani, the cuttings were transplanted into pots containing $1 / 2$ of substrate, $1 / 4$ of sand and $1 / 4$ of autoclaved soil. For inoculation, filter paper strips of each isolate of $F$. solani and of $F$. oxysporum f.sp. passiflorae were placed in Petri dishes containing PDA (potato-dextrose-agar) culture medium, and then incubated in BOD at $25{ }^{\circ} \mathrm{C}$ and a photoperiod of $12 \mathrm{hr}$. for seven days. After this time, a blade of each plate was made to ensure that all the isolates sporulated.

\subsubsection{F. solani}

The procedure of inoculation of the isolates of $F$. Solani was that described by Fischer et al. (2005b), in which a disk of culture medium containing the pathogen ( $5 \mathrm{~mm}$ diameter) was fixed with PVC plastic on a small wound in the plant stem at a height of $2 \mathrm{~cm}$ from the soil. The PVC plastic was removed five days after inoculation (DAI), and the same procedure was performed with the controls, except for the application of the fungus.

The experimental design consisted of randomized blocks with 17 treatments ( 16 isolates +1 control), with four replications and three plants per plot.

The clones of the inoculated UFV50 genotype were analyzed based on 13 characteristics, as described by Preisigke et al. (2015), which are:

a) lesion expansion, length and width (CE and LW);

b) number of plants in which the lesion reached less than $50 \%$ of the circumference (NPL-50\%);

c) period of inoculation until the lesion reached more than $50 \%$ of the circumference of the damaged plant stem $(\mathrm{PIL}+50 \%)$;

d) period of inoculation until the lesion reached $100 \%$ of the circumference of the damaged plant stem (PIL100\%);

e) number of plants in which the lesion reached the medulla (NPLRM);

f) normalized area below the expansion of lesion area curve (ABELAC);

g) normalized area below the expansion of lesion width curve (ABELWC);

f) normalized area below the expansion of lesion length curve (ABELLC);

i) period of inoculation until the plant wilts (IPPW);

j) number of dead plants (NDP);

k) survival period (SP); and

1) range of scores (RS).

The scores in each plot were used to calculate the Disease Index (DI) according to McKinney (1923). The evaluations of all treatments began on the 5 days post inoculation (DPI). They were carried out every two days until the $55^{\text {th }}$ DAI or until the death of the plant. At the end of the experiment, the isolates were re-isolated in order to complete the Koch Postulates.

Data evaluated were submitted to analysis of variance, and means were compared by Scott-Knott test at 5\% probability.

The genetic distance matrix estimation was performed based on Gower's algorithm (1971). Afterwards, the dendrogram was constructed using the UPGMA grouping method. The adjustment between the distances matrix and the dendrogram was estimated by the Cophenetic Correlation Coefficient (CCC) (Sokal and Rohlf, 1962). To establish a cut-off point in the dendrogram and to define the number of groups, the Mojena (1977) procedure was used based on the relative size of the merging (distances) levels in the dendrogram.

All analyses were performed using the GENES software (Cruz, 2016) with interaction of the "ape" package of the R software (R Development Core Team, 2014).

\subsubsection{F. oxysporum f.sp. passiflorae}

For the inoculation of the isolates, the washed root method was used. The seedlings were removed from the trays and the roots were washed in distilled water. Then, the roots were cut using sterile scissors and immersed in 100 $\mathrm{mL}$ conidia suspension in $400 \mathrm{~mL}$ plastic pots (the root was left in the suspension for 24 hours) (Preisigke et al., 2017). For the control, the procedure was the same, replacing only the suspension of conidia for distilled water. After the 24-hour period, the suspension was withdrawn, and $100 \mathrm{~mL}$ of nutrient solution was added as proposed by Clark (1975). This solution was changed every three days. 
The experimental design was randomized blocks with 9 treatments ( 8 isolates +1 control), with four replications and three plants per plot.

We evaluated the survival period (period in days from inoculation to plant death) and the number of live plants. Evaluations were carried out periodically up to 50 DAI. During this period, symptomatic seedlings had parts of their stem and roots disinfested and transferred to PDA medium to confirm the etiological agent. After data collection, the data were submitted to graphic dispersion using the means of the characteristics. The statistical analysis was performed using the Genes software (Cruz, 2016).

\subsection{Molecular Characterization and Population Structure}

For the extraction of genomic DNA, the monosporic isolates of $F$. solani and $F$. oxysporum $\mathrm{f}$. sp. passiflorae were grown in liquid potato dextrose agar (PDA) medium for two weeks. Subsequently, the mycelium was macerated in liquid nitrogen. DNA extraction was performed using extraction kit (Axygen Biosciences USA) according to the manufacturer.

The molecular characterization of the isolates was carried out by partial sequencing of the internal transcribed spacer (ITS) of the rDNA region. The primers ITS4 (5'-TCCTCCGCTTATTGATATGC-3') and ITS5 (GGAAGTAAAAGTCGTAACAAGG 5'-3') were used for amplification of the rDNA's ITS region (White et al., 1990). For $25 \mu \mathrm{l}$ of reaction, approximately $60 \mathrm{ng}$ of total DNA, $2.5 \mu \mathrm{l}$ of 10x PCR buffer, $2.5 \mathrm{mM}$ of each dNTP, $10 \mathrm{pMol}$ of each primer oligonucleotide, $1 \mathrm{U}$ of Taq polymerase and ultrapure $\mathrm{H}_{2} \mathrm{O}$ s.q.f. for $25 \mathrm{ml}$ were used. The amplification program consisted of an initial stage of denaturation at $94{ }^{\circ} \mathrm{C}$ for $2 \mathrm{~min}$, followed by 35 cycles at $94{ }^{\circ} \mathrm{C}$ for $45 \mathrm{~s}, 50{ }^{\circ} \mathrm{C}$ for $45 \mathrm{sec}$ and $72{ }^{\circ} \mathrm{C}$ for $1 \mathrm{~min}$, and a final step of stretching at $72{ }^{\circ} \mathrm{C}$ for $10 \mathrm{~min}$ in an Amplitherm thermocycler. The sequencing was performed by the Sanger method using the Big Dye Kit on the Applied Biosystem ABI3100 sequencer (Dunn \& Blattner, 1987).

The sequences obtained were edited and aligned using the BioEdit software (Hall, 1999), and then compared to sequences in the GenBank database using the NCBI BLAST software (www.ncbi.nlm.nih.gov). The phylogenetic tree was constructed using the MEGA software, version 5.0 (Tamura et al., 2011), and the Neighbor-Joining method with a bootstrap of 1,000 replications.

For the structuring of the populations, the Structure v2.3.4 software (Pritchard; Stephens; Donnelly, 2000) was used through clustering based on the Bayesian model. The structure of populations was classified into " $\mathrm{K}$ " clusters according to their genetic similarities. The number of clusters $(\mathrm{K})$ tested ranged from 1 to 10 , with 5 interactions each. The number of steps of the burnin length was 10,000 and the MCMC (Markov chain Monte Carlo) repetitions was 100,000 . To determine the number of genetic groups (most likely K), the criterion proposed by Evanno, Regnaut, and Goudet (2005) was used through the Structure Harvester v0.6.94 software (Earl \& Vonholdt, 2012).

\section{Results}

\subsection{Characterization of Aggressiveness F. solani}

By analyzing the data contained in the analysis of variance, it was possible to observe a significant difference between the means of the isolates at $1 \%$ probability by $\mathrm{F}$ test for almost all characteristics analyzed, except for LL, which was significant at $5 \%$.

By applying the Scott Knott test, the variables NPL-50\%, IPLR+50\%, NPLRM, IPPW and NDP separated the isolates into three groups, and the other variables into only two groups (Table 3). There was a marked variation for the characteristic IPLR+50\%: from 13 days (FSUNEMAT 25) to 50 days (FSUNEMAT 21, 28 and 35) among the isolates studied. Regarding the lesion expansion, the characteristic LL showed a mean variation from $14.72 \mathrm{~mm}$ (FSUNEMAT 7) to $77.86 \mathrm{~mm}$ (FSUNEMAT 25), and for LW from $3.52 \mathrm{~mm}$ (FSUNEMAT 50) to $13.54 \mathrm{~mm}$ (FSUNEMAT 25). 
Table 3. Aggressiveness averages of the 12 characteristics of 16 isolates of $F$. solani inoculated in P. edulis

\begin{tabular}{llllllll}
\hline Isolates & RS & SP & LE & LW & NPL-50\% & PIL+50\% & PIL100\% \\
\hline UNEMAT 4 & $55.55 \mathrm{~b}$ & $46.58 \mathrm{a}$ & $28,14 \mathrm{~b}$ & $6.35 \mathrm{~b}$ & $1.25 \mathrm{c}$ & $38.58 \mathrm{a}$ & $50.00 \mathrm{a}$ \\
UNEMAT 7 & $41.66 \mathrm{~b}$ & $42.99 \mathrm{a}$ & $14,72 \mathrm{~b}$ & $4.67 \mathrm{~b}$ & $2.00 \mathrm{~b}$ & $46.41 \mathrm{a}$ & $46.58 \mathrm{a}$ \\
UNEMAT 12 & $27.77 \mathrm{~b}$ & $46.91 \mathrm{a}$ & $15,74 \mathrm{~b}$ & $3.83 \mathrm{~b}$ & $2.50 \mathrm{a}$ & $47.25 \mathrm{a}$ & $47.41 \mathrm{a}$ \\
UNEMAT 17 & $30.55 \mathrm{~b}$ & $48.50 \mathrm{a}$ & $17,97 \mathrm{~b}$ & $3.75 \mathrm{~b}$ & $2.50 \mathrm{a}$ & $44.33 \mathrm{a}$ & $48.25 \mathrm{a}$ \\
UNEMAT 21 & $33.33 \mathrm{~b}$ & $46.25 \mathrm{a}$ & $15,68 \mathrm{~b}$ & $3.95 \mathrm{~b}$ & $2.75 \mathrm{a}$ & $50.0 \mathrm{a}$ & $50.00 \mathrm{a}$ \\
UNEMAT 25 & $91.66 \mathrm{a}$ & $34.49 \mathrm{~b}$ & $77,86 \mathrm{a}$ & $13.54 \mathrm{a}$ & $0.00 \mathrm{c}$ & $13.66 \mathrm{c}$ & $39.75 \mathrm{~b}$ \\
UNEMAT 28 & $19.44 \mathrm{~b}$ & $50.00 \mathrm{a}$ & $16,22 \mathrm{~b}$ & $5.36 \mathrm{~b}$ & $3.00 \mathrm{a}$ & $50.00 \mathrm{a}$ & $50.00 \mathrm{a}$ \\
UNEMAT 31 & $40.27 \mathrm{~b}$ & $46.25 \mathrm{a}$ & $24,15 \mathrm{~b}$ & $4.45 \mathrm{~b}$ & $2.00 \mathrm{a}$ & $45.75 \mathrm{a}$ & $49.25 \mathrm{a}$ \\
UNEMAT 33 & $69.44 \mathrm{a}$ & $43.99 \mathrm{a}$ & $47,93 \mathrm{a}$ & $12.54 \mathrm{a}$ & $0.50 \mathrm{c}$ & $19.00 \mathrm{c}$ & $36.99 \mathrm{~b}$ \\
UNEMAT 34 & $73.61 \mathrm{a}$ & $29.57 \mathrm{~b}$ & $41,24 \mathrm{a}$ & $9.17 \mathrm{a}$ & $0.25 \mathrm{c}$ & $15.00 \mathrm{c}$ & $33.75 \mathrm{~b}$ \\
UNEMAT 35 & $31.94 \mathrm{~b}$ & $43.66 \mathrm{a}$ & $19,03 \mathrm{~b}$ & $4.74 \mathrm{~b}$ & $2.50 \mathrm{a}$ & $50.00 \mathrm{a}$ & $50.00 \mathrm{a}$ \\
UNEMAT 38 & $48.61 \mathrm{~b}$ & $44.16 \mathrm{a}$ & $52,13 \mathrm{a}$ & $5.19 \mathrm{~b}$ & $2.00 \mathrm{~b}$ & $41.41 \mathrm{a}$ & $47.08 \mathrm{a}$ \\
UNEMAT 40 & $80.55 \mathrm{a}$ & $23.74 \mathrm{c}$ & $77,56 \mathrm{a}$ & $9.13 \mathrm{a}$ & $0.25 \mathrm{c}$ & $26.08 \mathrm{~b}$ & $28.58 \mathrm{~b}$ \\
UNEMAT 46 & $80.55 \mathrm{a}$ & $21.58 \mathrm{c}$ & $76,03 \mathrm{a}$ & $10.30 \mathrm{a}$ & $0.25 \mathrm{c}$ & $30.66 \mathrm{~b}$ & $43.66 \mathrm{a}$ \\
UNEMAT 47 & $66.66 \mathrm{a}$ & $33.91 \mathrm{~b}$ & $43,98 \mathrm{a}$ & $10.18 \mathrm{a}$ & $0.50 \mathrm{c}$ & $33.66 \mathrm{~b}$ & $44.00 \mathrm{a}$ \\
UNEMAT 50 & $48.60 \mathrm{~b}$ & $37.99 \mathrm{a}$ & $18,83 \mathrm{~b}$ & $3.52 \mathrm{~b}$ & $1.75 \mathrm{~b}$ & $46.75 \mathrm{a}$ & $50.00 \mathrm{a}$ \\
CONTROL & $20.83 \mathrm{~b}$ & $50.00 \mathrm{a}$ & $14,68 \mathrm{~b}$ & $2.46 \mathrm{~b}$ & $3.00 \mathrm{a}$ & $50.00 \mathrm{a}$ & $50.00 \mathrm{a}$ \\
VC & 37.10 & 17.33 & 96.38 & 53.97 & 40.37 & 25.97 & 16.23 \\
\hline
\end{tabular}

Note. Averages followed by the same letter in the columns do not differ from each other by the Scott Knott test at the $5 \%$ probability level. Characteristics of LE and LW are expressed in millimeters.

Table 3. Continued

\begin{tabular}{lllllll}
\hline \multirow{2}{*}{ Isolates } & \multicolumn{5}{c}{ Variables } \\
\cline { 2 - 7 } & NPLRM & ABELAC & ABELWC & ABELLC & IPPW & NDP \\
\hline UNEMAT 4 & $1.75 \mathrm{a}$ & $114.53 \mathrm{~b}$ & $32.31 \mathrm{~b}$ & $4.74 \mathrm{~b}$ & $46.08 \mathrm{a}$ & $0.25 \mathrm{c}$ \\
UNEMAT 7 & $1.00 \mathrm{~b}$ & $19.78 \mathrm{~b}$ & $17.00 \mathrm{~b}$ & $1.82 \mathrm{~b}$ & $42.41 \mathrm{a}$ & $0.75 \mathrm{c}$ \\
UNEMAT 12 & $0.50 \mathrm{c}$ & $24.08 \mathrm{~b}$ & $18.42 \mathrm{~b}$ & $2.27 \mathrm{~b}$ & $46.75 \mathrm{a}$ & $0.25 \mathrm{c}$ \\
UNEMAT 17 & $0.50 \mathrm{c}$ & $46.07 \mathrm{~b}$ & $24.50 \mathrm{~b}$ & $2.90 \mathrm{~b}$ & $48.00 \mathrm{a}$ & $0.25 \mathrm{c}$ \\
UNEMAT 21 & $0.25 \mathrm{c}$ & $29.91 \mathrm{~b}$ & $18.47 \mathrm{~b}$ & $2.83 \mathrm{~b}$ & $46.16 \mathrm{a}$ & $0.25 \mathrm{c}$ \\
UNEMAT 25 & $3.00 \mathrm{a}$ & $610.66 \mathrm{a}$ & $87.13 \mathrm{a}$ & $11.61 \mathrm{a}$ & $32.99 \mathrm{~b}$ & $1.50 \mathrm{~b}$ \\
UNEMAT 28 & $0.00 \mathrm{c}$ & $26.33 \mathrm{~b}$ & $19.00 \mathrm{~b}$ & $2.45 \mathrm{~b}$ & $50.00 \mathrm{a}$ & $0.00 \mathrm{c}$ \\
UNEMAT 31 & $1.00 \mathrm{~b}$ & $69.37 \mathrm{~b}$ & $31.62 \mathrm{~b}$ & $3.11 \mathrm{~b}$ & $45.16 \mathrm{a}$ & $0.50 \mathrm{c}$ \\
UNEMAT 33 & $2.50 \mathrm{a}$ & $381.61 \mathrm{a}$ & $61.16 \mathrm{a}$ & $9.73 \mathrm{a}$ & $43.24 \mathrm{a}$ & $0.50 \mathrm{c}$ \\
UNEMAT 34 & $2.75 \mathrm{a}$ & $265.34 \mathrm{~b}$ & $56.29 \mathrm{a}$ & $8.08 \mathrm{a}$ & $28.08 \mathrm{~b}$ & $1.75 \mathrm{~b}$ \\
UNEMAT 35 & $0.50 \mathrm{c}$ & $38.55 \mathrm{~b}$ & $22.72 \mathrm{~b}$ & $2.97 \mathrm{~b}$ & $43.16 \mathrm{a}$ & $0.50 \mathrm{c}$ \\
UNEMAT 38 & $1.00 \mathrm{~b}$ & $147.35 \mathrm{~b}$ & $57.44 \mathrm{a}$ & $3.80 \mathrm{~b}$ & $43.83 \mathrm{a}$ & $0.50 \mathrm{c}$ \\
UNEMAT 40 & $2.75 \mathrm{a}$ & $491.40 \mathrm{a}$ & $77.26 \mathrm{a}$ & $8.31 \mathrm{a}$ & $21.83 \mathrm{c}$ & $2.50 \mathrm{a}$ \\
UNEMAT 46 & $2.75 \mathrm{a}$ & $432.67 \mathrm{a}$ & $69.93 \mathrm{a}$ & $8.35 \mathrm{a}$ & $20.08 \mathrm{c}$ & $2.25 \mathrm{a}$ \\
UNEMAT 47 & $2.50 \mathrm{a}$ & $233.23 \mathrm{~b}$ & $58.77 \mathrm{a}$ & $7.25 \mathrm{a}$ & $33.24 \mathrm{~b}$ & $1.25 \mathrm{~b}$ \\
UNEMAT 50 & $1.25 \mathrm{~b}$ & $50.51 \mathrm{~b}$ & $25.77 \mathrm{~b}$ & $3.08 \mathrm{~b}$ & $37.33 \mathrm{a}$ & $1.00 \mathrm{c}$ \\
CONTROL & $0.00 \mathrm{c}$ & $18.92 \mathrm{~b}$ & $17.88 \mathrm{~b}$ & $1.81 \mathrm{~b}$ & $50.00 \mathrm{a}$ & $0.00 \mathrm{c}$ \\
VC & 45.42 & 55.34 & 68.94 & 51.24 & 18.76 & 74.12 \\
\hline
\end{tabular}

Note. Averages followed by the same letter in the columns do not differ from each other by the Scott Knott test at the $5 \%$ probability level. Characteristics of ABELAC, ABELWC and ABELLC are expressed in millimeters.

In this sense, the Gower's algorithm was used for the joint analysis of the 13 variables evaluated in this experiment in order to estimate the divergence of the aggressiveness of isolates of $F$. solani. The isolates FSUNEMAT 21 and FSUNEMAT 40 were the most distant in relation to aggressiveness, presenting a magnitude of 0.62 , while the isolates FSUNEMAT 12 and FSUNEMAT 17 were the most similar, with a value of 0.03 . It is noteworthy that the 
most distant isolates come from collections in different biomes, where one was collected in the Amazon and another in the Cerrado, while the most similar isolates were collected in the Amazon biome.

Based on the relative magnitude of the distances generated by the Gower's algorithm and the UPGMA grouping method, with a $75 \%$ cut-off point obtained by the Mojena method, there was the formation of two distinct groups (Figure 1). The dendrogram was representative of the matrix since the Cophenetic Correlation Coefficient (CCC) was 0.91, considered optimal. According to Vaz Patto et al. (2004), a CCC $>0.70$ already reflects a good agreement between the genetic distance matrix and the clustering method.

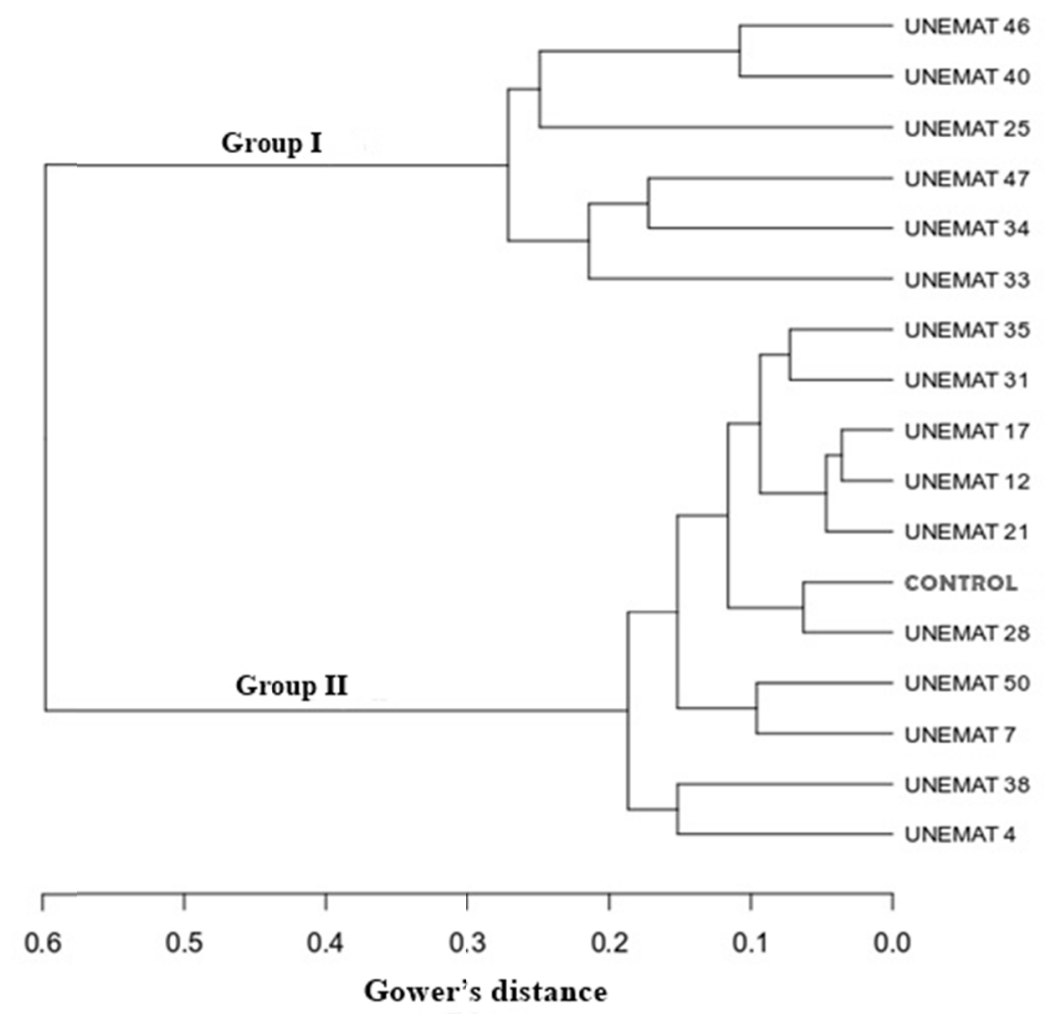

Figure 1. Dendrogram of genetic dissimilarities among 16 isolates of $F$. solani plus the control, obtained by the UPGMA method based on the Gower's algorithm, from 13 characters of aggressiveness

Thus, the isolates were divided into two groups. The Group I consisted of six isolates: FSUNEMAT 33, FSUNEMAT 34, FSUNEMAT 47, FSUNEMAT 25, FSUNEMAT 40 and FSUNEMAT 46. This group was formed by the most aggressive isolates of the UFV 50 cultivar, with a score of 5 in the grading scale (severe symptoms with extensive colonization of the plant collar, necrosis of the cortex and the plant medulla) and a lower SP. It also presented the highest mean values for ABELAC $(402.48 \mathrm{~mm})$, for ABELLC $(68.42 \mathrm{~mm})$ and ABELWC $(8.88 \mathrm{~mm})$. Among all isolates, FSUNEMAT 40 and FSUNEMAT 46 were the most aggressive and, consequently, caused most plant deaths. It is noteworthy that these isolates belong to the Cerrado and Pantanal biomes, respectively.

The Group II consisted of 10 isolates plus the control. The following characteristics were found in common: mild symptoms, necrosis in only part of the plant, i.e., less than $50 \%$ of the stem circumference, mean survival period of 45 days, mean ABELAC of $56.64 \mathrm{~mm}$, ABELLC of $26.72 \mathrm{~mm}$ and ABELWC of $2.99 \mathrm{~mm}$. The data reflect the low aggressiveness of these isolates to the cultivar UVF 50 of passion fruit. It is worth noting that the control did not show symptoms of the disease. However, due to an injury during the methodological procedure, a mean lesion length of $14.68 \mathrm{~mm}$ was observed.

\subsubsection{Molecular Characterization and Population Structure - F. solani}

In order to better understand the structuring of the population, we proceeded with the analysis via Structure. According to the proposed criterion, the model with $\mathrm{K}=2$ was considered as the best model to explain the genetic structure of the populations of $F$. solani (Figure 2). For this, two populations were formed, with clear combinations of genes from both gene pools. The isolates FSUNEMAT 12, 38, 40, 47 and 21 formed the population 1 and the 
population 2 was composed of the other isolates. It is noteworthy that the isolated FSUNEMAT 21 presented introgression of genes from the population 2, and that the isolates FSUNEMAT 50 and FSUNEMAT 7 presented gene combinations of the population 1 in the population 2 .

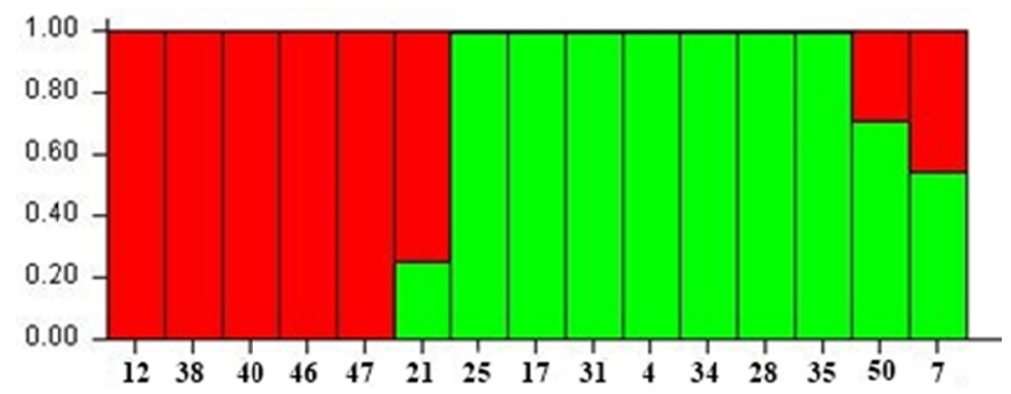

Figure 2. Genetic structure of populations of Fusarium solani when evaluated by $\mathrm{K}=2$ by the Structure Program. Each color indicates a population

The ITS region was amplified by PCR sequenced and compared with DNA sequences deposited in the GenBank, the phylogenetic tree was constructed for this region with 15 isolates. The isolate FSUNEMAT 33 was not used for phylogenetic tree construction because it did not present a significant alignment with sequences in the GenBank database (Figure 3).

The dendrogram generated from the sequencing of the ITS1 and ITS2 regions consisted of three distinct groups. Group I was formed by the highest number of isolates from a total of 10. This group consisted of isolates from the Pantanal and Amazon biomes. The Group II was composed only of two isolates, FSUNEMAT 47 (Cerrado) and FSUNEMAT 46 (Amazonia), while the group III was formed by three isolates belonging to the three biomes analyzed in this study.

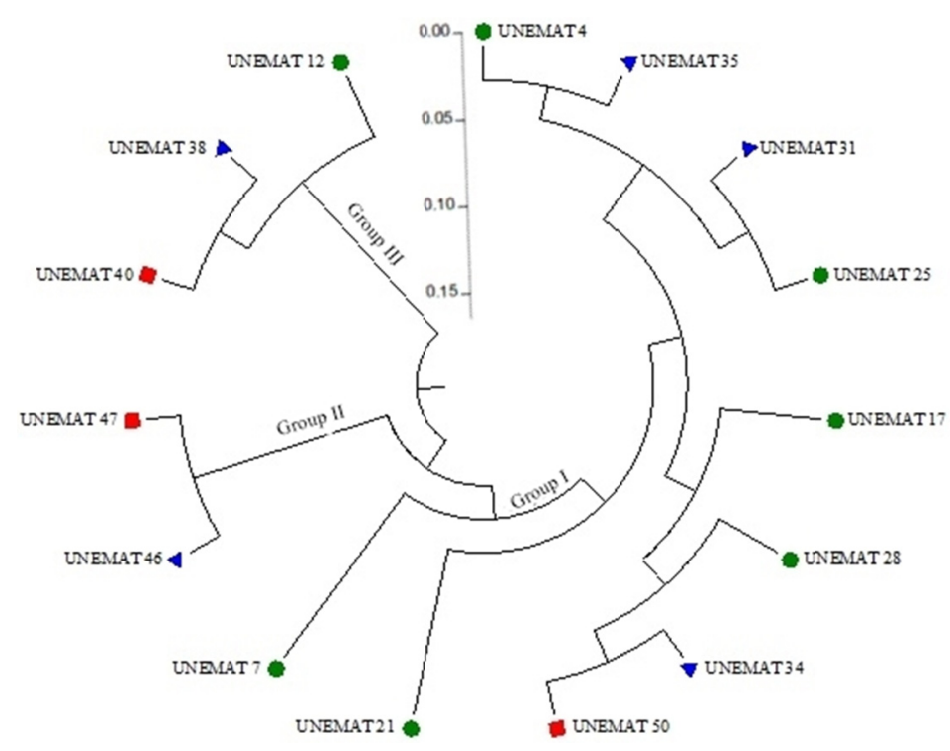

Figure 3. Phylogenetic tree based on the Neighbor-joining method derived from the sequences of the ITS 4 and ITS 5 regions of rDNA from Fusarium solani isolates

\subsection{Characterization of Aggressiveness-Fusarium oxysporum f.sp. passiflorae}

The analyzed variables presented significant differences among the means of the isolates at $1 \%$ probability by $\mathrm{F}$ test. For the variable survival period, the FOUNEMAT 22 isolate was the most aggressive because the average survival of plants did not exceed 17 days (Table 4). For this isolate, the symptoms in the plant appeared on the 5 
DPI, but on average, for the majority of isolates, the symptoms on the cuttings of $P$. edulis appeared on the tenth day after the inoculation. There was a death concentration of $P$. edulis between the 22 and the $25^{\text {th }}$ DPI for most isolates.

Table 4. Mean of the two aggressiveness characteristics of 8 isolates of $F$. oxysporum f.sp. passiflorae inoculated in P. edulis

\begin{tabular}{llc}
\hline \multirow{2}{*}{ Isolates } & \multicolumn{2}{c}{ Variables } \\
\cline { 2 - 3 } & Survival Period & Number of live plants \\
\hline UNEMAT 3 & $44.25 \mathrm{a}$ & $1.50 \mathrm{a}$ \\
UNEMAT 5 & $39.16 \mathrm{~b}$ & $1.50 \mathrm{a}$ \\
UNEMAT 6 & $40.16 \mathrm{~b}$ & $1.75 \mathrm{a}$ \\
UNEMAT 9 & $37.33 \mathrm{~b}$ & $1.00 \mathrm{a}$ \\
UNEMAT 13 & $38.58 \mathrm{~b}$ & $1.25 \mathrm{a}$ \\
UNEMAT 22 & $17.75 \mathrm{c}$ & $0.00 \mathrm{~b}$ \\
UNEMAT 41 & $43.24 \mathrm{a}$ & $1.75 \mathrm{a}$ \\
UNEMAT 43 & $33.24 \mathrm{~b}$ & $0.25 \mathrm{~b}$ \\
CONTROL & $48.91 \mathrm{a}$ & $2.50 \mathrm{a}$ \\
\hline
\end{tabular}

Note. Averages followed by the same letter in the columns do not differ by Scott Knott's test at $5 \%$ probability level.

According to the graphic dispersion obtained through aggressiveness characteristics, three groups were formed (Figure 6). The first group consisted only of the control, since it presented the highest values for the studied variables. The second group consisted of isolates with a moderate aggressiveness, which had a mean survival period of 39 days and a mean of 1.28 live plants at the end of the experiment. This group comprised $87.5 \%$ of the isolates.

The third group was formed by the isolate FOUNEMAT 22, which was the most aggressive. It presented the earliest symptoms in the stakes of $P$. edulis, besides providing the death of all the stakes until the $17^{\text {th }}$ day after inoculation (Figure 4).

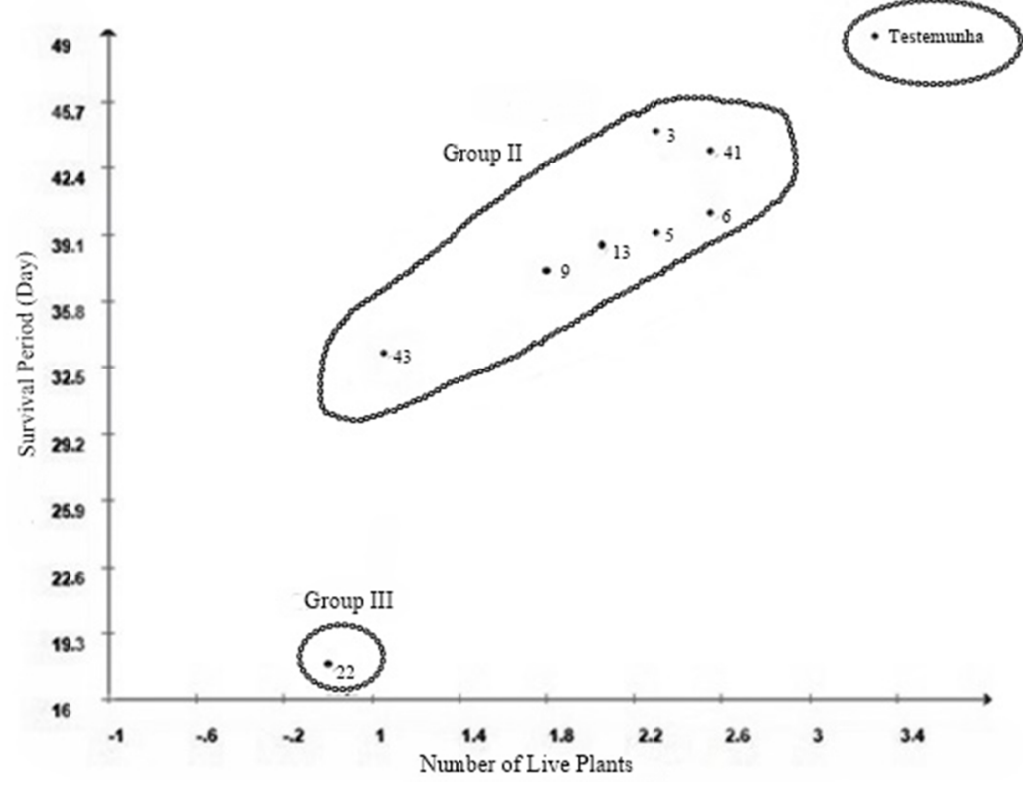

Figure 4. Graphic dispersion of characteristics: Number of Live Plants and Survival Period for eight isolates plus the control of Fusarium oxysporum f.sp. passiflorae 


\subsubsection{Molecular Characterization and Population Structure-F. oxysporum f.sp. passiflorae}

The results of the Bayesian analysis performed in the Structure program indicated the optimal value of $\mathrm{K}=3$. The value 3 was the lowest standard deviation and the $\log (\ln \mathrm{K})$ was closest to zero indicating that 3 is the most likely value for the group. The groupings can be seen in Figure 5. It is noted that the isolate FOUNEMAT 5 formed a single population, being the most divergent among all other isolates.



Figure 5. Genetic structure of populations of Fusarium oxysporum f.sp. passiflorae when evaluated by $\mathrm{K}=3$

As described in the molecular characterization section of $F$. sonali. by amplification, sequencing and alignment of the ITS1 and ITS2 regions, a genetic dissimilarity matrix and a dendrogram were generated. However, two from eight isolates of $F$. oxysporum f.sp. passiflorae, FOUNEMAT 41 and FOUNEMAT 43, showed no significant alignment with any GeneBank sequence and therefore were not used for the preparation of the dendrogram (Figure $6)$.

The phylogenetic tree based on the Neighbor-Joining method consisted of three groups. The first group consisted of the isolates FOUNEMAT 3, FOUNEMAT 22 and FOUNEMAT 13. This group includes an isolate collected in the Cerrado biome and other isolates collected from the Amazon biome. The second group was formed by the isolates FOUNEMAT 9 and FOUNEMAT 6, collected respectively in the Cerrado and Amazon biomes. Finally, the third group was composed of only one isolate, FOUNEMAT 5, which belongs to the Pantanal biome.

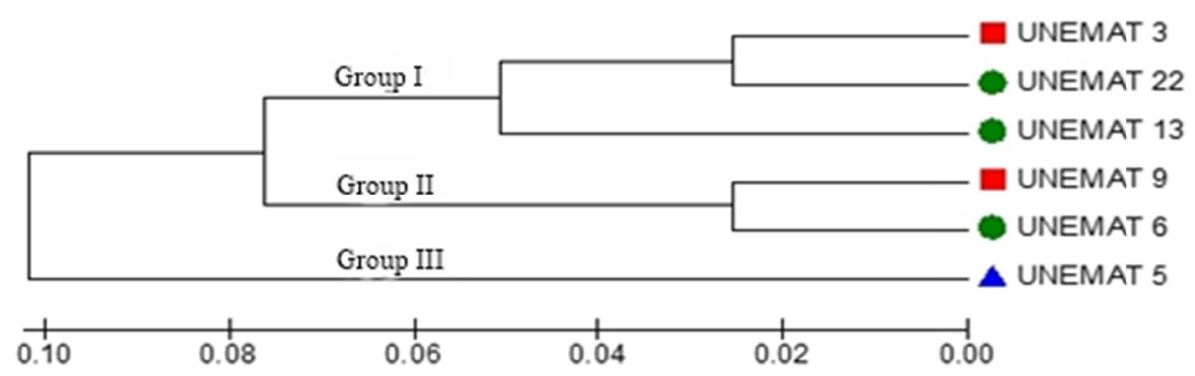

Figure 6. Dendrogram based on the Neighbor-joining method derived from the ITS 4 and ITS 5 region sequences of rDNA from Fusarium oxysporum f.sp. passiflorae isolates

\section{Discussion}

\subsection{Characterization of Aggressiveness - F. solani}

By the results, the groups formed by the UPGMA method, using Gower's distance, promoted a grouping that matched the degree of aggressiveness of the isolates.

Bueno et al. (2010) found similar results upon verifying the behavior of yellow passion fruit, variety Afruvec, in contact with a population of nine isolates of $F$. solani from the states of São Paulo and Rio de Janeiro. In the mentioned study, the fungus population presented a variability in relation to aggressiveness, ranging from isolates that did not cause death of plants, but caused a small lesion in the collar to isolates that caused a high number of plant mortality and large lesions in the collar.

Fischer et al. (2005b) also evaluated the behavior of two yellow passion fruit genotypes against five different isolates of $F$. solani. In that study, the authors found a great variability regarding the aggressiveness by the isolates 
(number of dead plants and length of injuries in the collar of the plants), and a variability in the resistance between the materials for each isolate.

By analogy between the biome of origin of the isolates studied here and the grouping formed, there was no relation between the degree of aggressiveness and the origin of the pathogen, that is, the isolates from the three biomes of the state of Mato Grosso (Pantanal, Cerrado and Amazon) were distributed indistinctly in the groups formed.

These data corroborate those of Nakatina et al. (2009) upon studying the variability of five pathogenic isolates of Xanthomonas axonopodis pv. passiflorae collected at four different locations in the state of São Paulo. In that study, the authors verified the existence of variability in the aggressiveness of the isolates when inoculated in sour passion fruit. However, there was no evident relation between the collection site and the groups' composition. This is different from what was found by Munhoz et al. (2011) by working with isolates of X. axonopodis pv. passiflorae. The authors noticed a relation between the collection region and the genetic diversity of the isolates.

In addition, Dariva et al. (2015) found a high intraspecific genetic variability for isolates of $F$. solani using the molecular markers ISSR and RAPD, but there was also no clustering of isolates according to the geographic region of origin.

From a technical point of view, the genetic variability observed for the pathogen's aggressiveness $(F$. solani) to $P$. edulis may be related to the genetic variability of the genus Passiflora since Brazil is an important center of diversity of this genus, and generally the centers of diversity of the hosts are also centers of diversity of pathogens (Leppik. 1970). It is interesting to emphasize that there is a co-evolution process between pathogen and host, generating variability in both plant and fungal populations, which are usually associated with evolutionary forces, such as mutation, migration and selection (Barbieri \& Carvalho, 2001). In addition, another explanation would be the existence of the sexed phase of this fungus, which belongs to the genus Haematonectria, where there is genetic recombination and the possibility of crossing between different individuals (Fischer et al., 2005a; Nayaka et al., 2011; Dufresne et al., 2011).

\subsubsection{Molecular Characterization and Population Structure-F. solani}

According to the results, a great genetic diversity was verified among the isolates of $F$. Solani studied. This high variability was also observed by Bahar and Shahab (2012) upon investigating 33 isolates of F. solani collected in different regions of Iran and characterized by marked SSR. The DNA analysis showed that the isolates had a high genetic variability and formed 10 distinct groups in the phylogenetic tree.

In studies on passion fruit, Henao-Henao et al. (2018) analyzed populations of Fusarium spp. associated with $P$. edulis in five municipalities of Valle del Cauca. Colombia. They analyzed 35 isolates by amplifying the region of the TEF 1 alpha gene, and identified three species of Fusarium, among them F. solani.

In this same context, using the ITS-5.8S region sequencing and the elongation factor $1 \alpha(\mathrm{EF}-1 \alpha)$. Bueno et al. (2014) verified an interspecific variability of eight $F$. solani isolates from $P$. edulis. The authors identified that the isolates had host specificity and that the phylogenetic trees of the ITS and EF-1a region showed that the isolates formed a distinct group within the $F$. solani group when compared to other GenBank sequences.

In view of these results, the isolates of F. solani collected in P. edulis in the state of Mato Grosso presented a high molecular variability independent from the biome of origin, and this was also observed in the tests of aggressiveness.

\subsection{Characterization of Aggressiveness-Fusarium oxysporum f.sp. passiflorae}

All isolates of $F$. oxysporum f.sp. passiflorae were pathogenic. However, the analysis of aggressiveness showed a variation among isolates classified as aggressive and moderately aggressive. Similar results were found by Cunha et al. (2015) working with different isolates of Fusarium oxysporum f. sp. cubense collected in the north and south of the state of Santa Catarina. Brazil. The authors identified that the isolates from Bananeiras of the Pome subgroup were only classified as aggressive (88.5\%) and moderately aggressive (11.5\%). None was classified as little aggressive.

The data indicate that there is no relationship between the aggressiveness of the isolates analyzed in this study and their biome of origin. This also occurred with the isolates of $F$. solani. This is probably due to a horizontal transfer of genes between lineages in the species under study.

Baayen et al. (2000) found that formae speciales in the complex of $F$. oxysporum might have independent origins. Pathogenicity and virulence evolve through mutations, transposition or dissemination to distant related organisms through parasexuality or horizontal transfer of genes. 
Faced with these facts, Hua-Van et al. (2001) reported that the transposition of DNA sequences into the genome might result in genetic, intra- and inter-specific variability. They also point out that, from an evolutionary point of view, there is the possibility of a horizontal transfer of genes between different species, as observed in an experiment on isolates of $F$. oxysporum.

\subsubsection{Molecular Characterization and Population Structure-F. oxysporum f.sp. passiflorae}

According to results obtained by molecular analysis, the groups formed demonstrate a high degree of diversity among the isolates of $F$. oxysporum f.sp. passiflorae. It should be noted that the isolate FOUNEMAT 5 from the Pantanal biome was the most divergent because it was allocated alone in a group. Note that the clusters formed in the population structure analysis coincide with the groups generated by the phylognetic tree using the Neighbor-Joining method.

Other authors also found a high molecular genetic diversity among isolates of $F$. oxysporum f.sp. passiflorae. Silva et al. (2013), using AFLP markers, observed a high variability among 14 isolates of $F$. oxysporum f.sp. passiflorae collected in Bahia. Dariva et al. (2014) determined the genetic variability of 13 isolates of F. oxysporum f.sp. passiflorae pathogenic to passion fruit by using ISSR and RAPD markers. The analyses revealed a population with a high intra-population genetic variability.

Similar results were found by Walker et al. (2016) using the ITS1 and ITS4 markers on Fusarium acuminatum and Fusarium verticillioides. The authors were able to genetically dissociate these isolates from others of the genus Fusarium.

Contrary to what was found in this study in Iran, Nourollahi and Madahjalali (2017) determined the population structure and the genetic diversity of 101 isolates of Fusarium oxysporum f. sp. lentis by SSR markers. The results showed a high genetic similarity between the isolates probably due to a low gene flow in the collection region.

By making an analogy between the results obtained with the molecular and aggressive tests. a high genetic and pathogenic variability of the isolates can be observed regardless of the biome of origin.

\section{Conclusion}

The results indicate a need to consider the molecular variability and the aggressiveness of the pathogens $F$. solani and F. oxysporum f.sp. passiflorae in the evaluation of genotypes of sour passion fruit in programs of selection of resistant cultivars. The genetic structure of pathogen populations may provide insights into the pathogen's evolutionary potential, as well as lead to the development of integrated disease management strategies and breeding programs. The use of the most aggressive pathogens in this study is recommended for the selection of resistant genotypes of Passiflora spp. Among all isolates of the $F$. solani, FSUNEMAT 40 and FSUNEMAT 46 were the most aggressive and of the $F$. oxysporum f.sp. passiflorae the most aggressive was FOUNEMAT 22.

\section{References}

Amorim, L., Rezende, J. A. M., Bergamim Filhoe, A., \& Camargo, L. E. A. (2016). Manual de fitopatologia (p. 820). São Paulo. Agronômica Ceres.

Baayen, R. P., O’donnell, K., Bonants, P. J. M., Cigelnik, E., Kroon, L. P. N. M., Roebroeck, E. J. A., \& Waalwijk, C. (2000). Gene genealogies and AFLP analysis in the Fusarium oxysporum complex identify monophyletic and non-monophyletic formae speciales causing wilt and rot diseases. Phytopathology, 90, 891-900. https://doi.org/10.1094/PHYTO.2000.90.8.891

Bahar, M., \& Shahab, H. (2012). Analysis of Iranian isolates of Fusarium solani using morphological. pathogenicity and microsatellite DNA marker characterization. African Journal of Biotechnology, 11, 474-482.

Barbieri, R. L., \& Carvalho, F. I. F. (2001). Coevolução de plantas e fungos patogênicos. Rev. Bras. de Agrociência, 7, 79-83.

Bespalhok Filho, J. C. (1999). Melhoramento para Resistência a Doenças. In D. Destro, \& R. Montalvan (Eds.), Melhoramento Genético de Plantas (pp. 11-18). Londrina: UEL.

Parisi, M. C. M., \& Furtado, E. L. (2010). Comportamento do maracujazeiro amarelo, variedade afruvec, ante uma população de Fusarium solani, agente causal da podridão do colo. Arq. Inst. Biol., 77, 533-537.

Bueno, C. J., Ambrosio, M. M. Q., \& Souza, N. L. (2006). Preservação de fungos fitopatogênicos habitantes do solo. Summa Phytopathologica, 32, 42-50. https://doi.org/10.1590/S0100-54052006000100006 
Bueno, C. J., Fischer, I. H., Rosa, D. D., Firmino, A. C., Harakava, R., Oliveira, C. M. G., \& Furtado, E. L. (2014). Fusarium solani f. sp. passiflorae: A new forma specialis causing collar rot in yellow passion fruit. Plant Pathology, 63, 382-389. https://doi.org/10.1111/ppa.12098

Carvalho, A. B., Coelho, V. J., Araújo, K. L., Siqueira, K. A., Neves, S. M. A. S., Soares, M. A., \& Neves, L. G. (2015). Genetic variability of Fusarium solani and Fusarium oxysporum f. sp. passiflorae isolates from Pantanal, Amazon and Cerrado biomes of Mato Grosso. Brazil. Afr. J. Agric. Res., 10(53), 4990-4997. https://doi.org/10.5897/AJAR2015.10354

Clark, R. B. (1975). Characterization of phosphates in intact maize roots. Journal of Agricultural and Food Chemistry, 23, 458-460. https://pubs.acs.org/doi/abs/10.1021/jf60199a002

Cruz, C. D. (2016). Programa Genes-Aplicativo Computacional em Genética. Retrieved from http://www. ufv.br/dbg/genes/Genes_Br.htm

Cunha, C. M. S., Hinz, R. H., Pereira, A., Tcacenco, F. A., \& Stadnik, M. J. (2015). Aggressiveness and genetic diversity of Fusarium oxysporum f. sp. cubense from Santa Catarina, southern Brazil. Trop. Plant Pathol., 40, 326-334. https://doi.org/10.1007/s40858-015-0046-4

Dariva, J. M., Xavier, A. A., Costa, M. R., Ribeiro, R. C. F., \& Sousa, T. V. (2015). Variabilidade genética de isolados de Fusarium solani e Fusarium oxysporum f. sp. passiflorae associados ao maracujazeiro. Rev. Bras. Frutic., 37, 377-386. https://doi.org/10.1590/0100-2945-119/14

Dufresne, M., Lespinet, O., Daboussi, M. J., \& Hua-Van, A. (2011). Genome-Wide Comparative Analysis of Pogo-Like Transposable Elements in Different Fusarium Species. J. Mol. Evol., 73, 230-243. https://doi.org/10.1007/s00239-011-9472-1

Dunn, I. S., \& Blattner, F. R. (1987). Charons 36 to 40: Multienzyme, high capacity, recobination deficient replacement vectors with polylinkers and polystuffers. Nucleic Acids Res, 15, 2677-2698. https://doi.org/ 10.1093/nar/15.6.2677

Earl, D. A., \& Vonholdt, B. M. (2012). STRUCTURE HARVESTER: A website and program for visualizing STRUCTURE output and implementing the Evanno method. Conservation Genetics Resources, 4, 359-361. https://doi.org/10.1007/s12686-011-9548-7

Evanno, G., Regnaut, S., \& Goudet, J. (2005). Detecting the number of clusters of individuals using the software structure: A simulation study. Mol Ecol, 14, 2611-2620. https://doi.org/10.1111/j.1365-294X.2005.02553.x

Fischer, I. H., \& Rezende, J. A. (2008). Disease of Passion flower (Passiflora spp.). Pest Technology, 2, 1-19.

Fischer, I. H., Kimati, H., \& Rezende, J. A. M. (2005a). Doenças do maracujazeiro (Passiflora spp.). In H. Kimati, L. Amorim, J. A. M. Rezende, A. Bergamin Filho, \& L. E. A. Camargo (Eds.), Manual de fitopatologia: Doenças das plantas cultivadas (pp. 467-474). São Paulo: Agronômica Ceres.

Fischer, I. H., Lourenço, S. A., Martins, M. C., Kimati, H., \& Amorim, L. (2005b). Seleção de plantas resistentes e de fungicidas para o controle da podridão do colo do maracujazeiro causada por Nectria hematococca. Fitopatologia Brasileira, 30, 250-258. https://doi.org/10.1590/S0100-41582005000300006

Fry, W. E. (1977). Integrated control of potatoes late blight: Effects of polygenic resistance and techniques of timing fungicide application. Phytopathology, 67, 415-420. https://doi.org/10.1094/Phyto-67-415

Gower, J. C. (1971). A general coefficient of similarity and some of its properties. Biometrics, 27, 857-874. https://doi.org/10.2307/2528823

Henao-Henao, E. D., Hernández-Medina, C. A., Salazar-González, C., Velasco-Belalcazar, M. L., \& Gómez-López, E. D. (2018). Molecular identification of Fusarium isolates associated with passion fruit in five locations from Valle del Cauca, Colombia. Agron Mesoam, 29, 53-61. https://doi.org/10.15517/ ma.v29i1.27114

Hua-Van, A. M., Pamphile, J. A., Langin, T., \& Daboussi, M. J. (2001). Trans-position of autonomous engineered impala transposons in Fusarium oxysporum and a related species. Mol Gen Genet, 264, 724-31. https://doi.org/10.1007/s004380000426

IBGE. (2016). Produção Agrícola Municipal. Retrieved from ftp://ftp.ibge.gov.br/Producao_Agricola/Producao_ Agricola_Municipal_[anual]/2016/pam2016.pdf

Junqueira, N. T. V., Braga, M. F., Faleiro, F. G., Peixoto, J. R., \& Bernacci, L. C. (2005). Potencial de espécies silvestres de maracujazeiro como fonte de resistência a doenças. In F. G. Faleiro, N. T. V. Junqueira, \& M. F. 
Braga (Eds.), Maracujá, germoplasma e melhoramento genético (pp. 81-108). Planaltina, Embrapa Cerrados.

Leppik, E. E. (1970). Gene centers of plants as sources of disease resistance. Annual Review of Phytopathology, 8, 323-344. https://doi.org/10.1146/annurev.py.08.090170.001543

MAPA. (2016). Plano Agrícola e Pecuário. Retrieved from http://www.agricultura.gov.br/arq_editor/PAP\%2020 14-2015.pdf

McKinney, H. H. (1923). Influence of soil, temperature and moisture on infection of wheat seedlings by Helminthosporium sativum. Journal of Agricultural Research, 26, 195-217.

Mojena, R. (1977). Hierarchical grouping methods and stopping rules: An evaluation. The Computer Journal, 20, 359-363. https://doi.org/10.1093/comjnl/20.4.359

Munhoz, C. F., Weiss, B., Hanai, L. R., Zucch, I. M. I., Fungaro, M. H. P., Oliveira, A. L. M., Monteiro-Vitorello, C. B., \& Vieira, M. L. C. (2011). Genetic diversity and a PcR-based method for Xanthomonas axonopodis detection in passion fruit. Phytopathology, 101, 416-24. https://doi.org/10.1094/PHYTO-06-10-0169

Nakatini, A. K., Lopes, R., \& Camargo, L. E. A. (2009). Variabilidade genética de Xanthomonas Axonopodis Pv. Passiflora. Summa Phytopathol, 35, 116-120. https://doi.org/10.1590/S0100-54052009000200006

Nayaka, S. C., Wulff, E. G., Udayashankar, A. C., Nandini, B. P., \& Niranjana, S. R. (2011). Prospects of molecular markers in Fusarium species diversity. Applied Microbiology and Biotechnology, 90, 1625-1639. https://doi.org/10.1007/s00253-011-3209-3

Nourollahi, K., \& Madahjalali, M. (2017). Analysis of population genetic structure of Iranian Fusarium oxysporum f. sp. lentis isolates using microsatellite markers. Australasian Plant Pathol, 46, 35-42. https://doi.org/10.1007/s13313-016-0458-8

Novaes, Q. S. (2005). Recomendações técnicas para o cultivo de maracujá amarelo nos municípios de Livramento de Nossa Senhora e Dom Basílio (p. 27). SEBRAE, Boletim Técnico.

Paula, M. S., Fonseca, M. E. N., Boiteux, L. S., \& Peixoto, J. R. (2010). Caracterização genética de espécies de Passiflora por marcadores moleculares análogos a genes de resistência. Revista Brasileira de Fruticultura, 32, 222-229. https://doi.org/10.1590/S0100-29452010005000021

Preisigke, S. C., Martini, F. V., Rossi, A. A. B., Serafim, M. S., Barelli, M. A. A., Luz, P. B., ... Neves, L. G. (2015). Genetic variability of Passiflora spp. against collar rot disease. Australian Journal of Crop Science, 9, 69-74.

Preisigke, S. C., Silva, L. P., Serafim, M. E., Bruckner, C. H., Araújo, K. L., \& Neves, L. G. (2017). Seleção precoce de espécies de Passiflora resistente a fusariose. Summa Phytopathologica, 43, 321-325. https://doi.org/10.1590/0100-5405/175390

Pritchard, J. K., Stephens, M., \& Donnelly, P. (2000). Inference of population structure using multilocus genotype data. Genetics, 155, 945-959. https://doi.org/10.1111/j.1471-8286.2007.01758.x

$\mathrm{R}$ Development Core Team. (2016). A language and environment for statistical computing. Vienna: R Foundation for Statistical Computing.

Roy, K. (1997). W. Fusarium solani on soybean roots: Nomenclature of the causal agent of sudden death syndrome and identity and relevance of F. solani form B. Plant Disease, 81, 259-266. https://doi.org/10.109 4/PDIS.1997.81.3.259

Shaner, G., \& Finney, R. E. (1997). The effect of nitrogen fertilization on the expression of slow-mildewing resistence in Knox wheat. Phytopathology, 67, 1051-1056.

Silva, A. S., Oliveira, E. J., Haddad, F., Jesus, O. N., Oliveira, S. A. S., \& Costa, M. A. P. (2013). Variação genética em isolados de Fusarium oxysporum f. sp. passiflorae com marcadores AFLP. Scientia Agricola, 70, 108-115. https://doi.org/10.1590/S0103-90162013000200008

Silva, R. M., Ambrósio, M. M. Q., Aguiar, A. V. M., Faleiro, F. G., Cardoso, A. M. S., \& Mendonça. V. (2017). Reação de cultivares de mracujazeiro em áreas com fusariose. Summa Phytopathopatologica, 43, 98-102. https://doi.org/10.1590/0100-5405/2217

Sokal, R. R., \& Rohlf, F. J. (1962). The comparison of dendrograms by objective methods. Taxonomy, 11, 30-40. https://doi.org/10.2307/1217208 
Tamura, K., Peterson, D., Peterson, N., Stecher, G., Nei, M., \& Kumar, S. (2011). MEGA5: molecular evolutionary genetics analysis using maximum likelihood, evolutionary distance, and maximum parsimony methods. Mol Biol Evol, 28, 2731-2739. https://doi.org/10.1093/molbev/msr121

Vaz Patto, M. C., Satovic, Z., Pêgo, S., \& Fevereiro, P. (2004). Assessing the genetic diversity of Portuguese maize germoplasm using microsatellite markers. Euphytica, 137, 63-72. https://doi.org/10.1023/B:EUPH.0 000040503.48448 .97

Walker, C., Maciel, C. G., Milanesi, P. M., Muniz, M. F. B., Mezzomo, R., \& Pollet, C. S. (2016). Morphological, molecular and patogenicity characterization of Fusarium acuminatum and Fusarium verticillioides to Cordia Americana seeds. Ciência Florestal, 26, 463-473. https://doi.org/10.5902/1980509822747

\section{Appendix A}

NCBI ID information for each fungal isolate used in this research

\begin{tabular}{|c|c|c|}
\hline $\mathrm{N}^{0}$ of Collection & NCBI/GenBank & \% Query Cover \\
\hline \multicolumn{3}{|l|}{ Fusarium solani } \\
\hline FSUNEMAT 4 & MG734215.1 & $96 \%$ \\
\hline FSUNEMAT 7 & MH559637.1 & $99 \%$ \\
\hline FSUNEMAT 12 & KM979504.1 & $99 \%$ \\
\hline FSUNEMAT 17 & MH794181.1 & $98 \%$ \\
\hline FSUNEMAT 21 & MG679522.1 & $86 \%$ \\
\hline FSUNEMAT 25 & KM678345.1 & $93 \%$ \\
\hline FSUNEMAT 28 & KM678345.1 & $93 \%$ \\
\hline FSUNEMAT 31 & MF510588.1 & $99 \%$ \\
\hline FSUNEMAT 33 & MF510588.1 & $99 \%$ \\
\hline FSUNEMAT 34 & KU097248.1 & $94 \%$ \\
\hline FSUNEMAT 35 & KU097247.1 & $94 \%$ \\
\hline FSUNEMAT 38 & KR071141.1 & $94 \%$ \\
\hline FSUNEMAT 40 & KU097248.1 & $94 \%$ \\
\hline FSUNEMAT 46 & KR071141.1 & $94 \%$ \\
\hline FSUNEMAT 47 & KU097247.1 & $94 \%$ \\
\hline FSUNEMAT 50 & МH794181.1 & $99 \%$ \\
\hline \multicolumn{3}{|c|}{ Fusarium oxysporum f. sp. passiflorae } \\
\hline FOUNEMAT 3 & DQ979012.1 & $99 \%$ \\
\hline FOUNEMAT 5 & MG669176.1 & $94 \%$ \\
\hline FOUNEMAT 6 & MH368097.1 & $84 \%$ \\
\hline FOUNEMAT 9 & MH665483.1 & $97 \%$ \\
\hline FOUNEMAT 13 & МH368097.1 & $99 \%$ \\
\hline FOUNEMAT 22 & MG664775.1 & $99 \%$ \\
\hline FOUNEMAT 41 & MG664774.1 & $99 \%$ \\
\hline FOUNEMAT 43 & MH879859.1 & $99 \%$ \\
\hline
\end{tabular}

\section{Copyrights}

Copyright for this article is retained by the author(s). with first publication rights granted to the journal.

This is an open-access article distributed under the terms and conditions of the Creative Commons Attribution license (http://creativecommons.org/licenses/by/4.0/). 